\title{
PENERAPAN ILMU PENGETAHUAN DAN TEKNOLOGI MESIN PENGUPAS KULIT ARI KEDELAI JENIS SCREW PADA INDUSTRI KECIL TEMPE
}

\author{
Andika Wisnujati \\ Jurusan Teknik Mesin Politeknik Muhammadiyah Yogyakarta (Politeknik UMY) \\ Email : andikawisnujati@umy.ac.id
}

\begin{abstract}
Soybeans are nutritious foods that contain lots of protein. Foods made from soy beans that are often found is tempeh. The process production tempeh in Indonesia, both in industries or traditional scale are basically similar. The difference lies in the way of peeling the cuticle soybean seeds. Peeling skin soybeans traditionally have weaknesses, among others, in terms of time this process takes a long time, and in terms of cleanliness and health of the process is very unhygienic. It is necessary to develop technologies and equipment to peeling the husk, clean and hygienic. The purpose of this study is to determine the optimum rotation soybeans the cuticle peeler and economic analysis.

The design of manufacturing soybean the cuticle peeler using a variable rotation speed (rpm) based on the diameter of pulley: 10, 8, 7, 6, and 5-inch, clearance space: 2.0; 2.25, and $2.5 \mathrm{~mm}$. The result is a soybean seed husk is peeled and cut into 2 (two). Manufacturing peeler cuticle of soybean type of screw and the high of pegs for soybean industry began with the design of forms, image design, selection of materials and processed with standard production equipment and test its performance. Optimization testing soybean peeler the cuticle by the rotation speed between the end of the peeler cylinder (cylindrical mill) with the body cylinder mill with a production capacity and testing variations size of pulley.

Based on the test results it can be concluded that the optimal results peeler cuticle of soybean type of screw, the rotational speed in $386 \mathrm{rpm}$ and 10 inches in diameter pulley and also in $2.5 \mathrm{~mm}$ of clearance space.
\end{abstract}

Keywords: Optimization, Soybean Cuticle Peeler, Capacity, Soybean Tempeh.

\section{PENDAHULUAN}

Kedelai adalah makanan bergizi yang banyak mengandung protein. Kedelai saat ini banyak dikonsumsi oleh masyarakat Indonesia karena kacang kedelai dapat dibuat berbagai macam makanan, seperti : tahu, tempe, kecap, tauco, dan susu kedelai. Kedelai dikenal dengan berbagai nama: sojaboom, soja, soja bohne, soybean, kedele, kacang ramang, kacang bulu, kacang gimbol, retak mejong, kaceng bulu, kacang jepun, dekenana, demekun, dele, kadele, kadang jepun, lebui bawak, lawui, sarupapa tiak, dole, kadule, puwe mon, kacang kuning (aceh) dan gadelei. Berbagai nama ini menunjukkan bahwa kedelai telah lama dikenal di Indonesia. (Anonim, 2010).

Tempe pada umumnya terbuat dari biji kacang kedelai dan dihasilkan dari industri rumah tangga atau industri kecil. Pembuatan tempe dari bahan baku kedelai di Indonesia baik dalam skala industri maupun tradisional pada dasarnya hampir sama. Perbedaannya terletak pada cara pengupasan kulit ari biji kedelainya. Biji kacang kedelai yang akan dibuat tempe harus bersih dari kulit ari yang masih menempel pada biji tersebut. Secara tradisional, pengupasan kulit ari pada biji kacang kedelai dengan cara biji kacang kedelai direndam terlebih dahulu dalam suatu wadah. Dengan merendam, kacang kedelai akan menyerap banyak air sehingga ukurannya menjadi besar, kemudian kacang 
kedelai direbus, ditunggu hingga hangat kemudian biji kacang kedelai dimasukkan dalam ember plastik besar dan diinjak-injak menggunakan kaki manusia, selanjutnya dicuci dengan air beberapa kali hingga kulit ari yang menggambang terbuang. Pengupasan kulit ari kedelai secara tradisional ini mempunyai kelemahan antara lain dilihat dari segi waktu proses ini memakan waktu yang lama, dan dari segi kebersihan dan kesehatan proses ini sangat tidak higienis. Perlu dikembangkan teknologi dan peralatan pengupasan kulit ari kedelai yang cepat, bersih dan higienis.

Tujuan dari perencanaan ini antara lain :

a. Menentukan putaran optimum mesin pengupas kulit ari kedelai untuk proses pembuatan tempe untuk mendapatkan hasil pengupasan yang baik.

b. Melakukan analisis ekonomi penggunaan alat pengupas kulit ari kedelai jenis screw pada industri rumah tangga pembuat tempe kedelai.

\section{TINJAUAN PUSTAKA}

\subsection{Tempeh}

Tempe adalah makanan yang dibuat dari fermentasi terhadap biji kedelai atau beberapa bahan lain yang menggunakan beberapa jenis kapang Rhizopus, seperti Rhizopus oligosporus, $R h$. oryzae, Rh. stolonifer (kapang roti), atau Rh. arrhizus.

Secara umum, tempe berwarna putih karena pertumbuhan miselia kapang yang merekatkan biji - biji kedelai sehingga terbentuk tekstur yang memadat. Degradasi komponen - komponen kedelai pada fermentasi membuat tempe memiliki rasa dan aroma khas.

Berdasarkan hasil penelitian yang dilakukan oleh balai besar penelitian industri hasil pertanian di Bogor, kadar protein dalam kedelai berbeda jauh apabila dibandingkan dengan kadar protein dalam tempe.
Tabel 1. Perbandingan Kadar Protein Dalam Kedelai dan Tempe.

\begin{tabular}{|l|l|l|l|}
\hline Num & Type of element & $\begin{array}{c}\text { Soybean } \\
(\%)\end{array}$ & $\begin{array}{c}\text { Tempeh } \\
(\%)\end{array}$ \\
\hline 1 & Protein & 35 to 40 & 15 \\
\hline 2 & Carbohydrate & 2 & 5 \\
3 & Fat & 20 & 5 \\
\hline 4 & Water content & 9.25 & 62.5 \\
\hline
\end{tabular}

\section{Alat Pengupas Kulit Ari Kedelai}

2.2. Mekanisme Rol Batu Gerinda

Mekanisme satu buah batu gerinda yang berputar bergesekan dengan rumahnya digunakan oleh Suryawinata (2006) pada mesin pengupas kulit ari kacang kedelai. Batu gerinda diberi jarak sekitar 2 (dua) kali diameter kacang kedelai. Kacang kedelai yang masuk akan bergesekan dengan batu gerinda, rumah pengupas, dan dengan kacang kedelai itu sendiri.
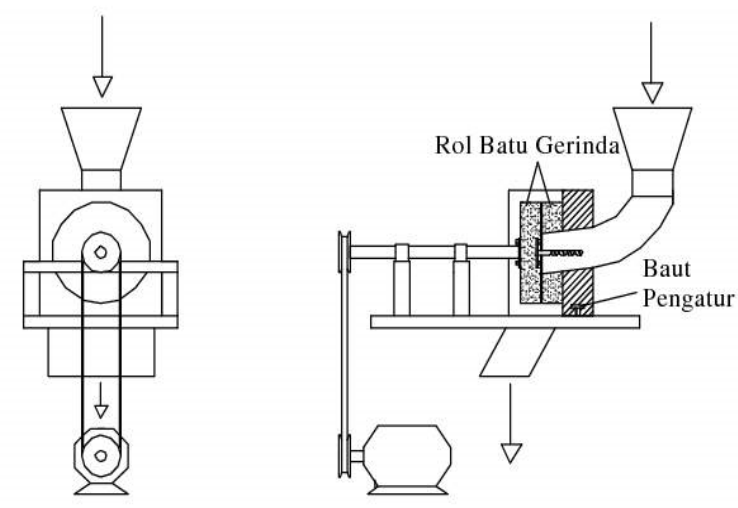

Gambar 1. Mekanisme Rol Batu Gerinda.

\subsection{Soybean Miller Machine in "screw type"}

Menurut Hasim (2002), yang mendesain mesin penggiling kedelai untuk pembuatan tempe menggunakan bahan kayu sono keeling dan digerakkan secara manual dengan peralatan engkol, menghasilkan kapasitas produksi $4 \mathrm{~kg} / 15$ menit dengan system poros berulir screw yang didorong maju yang bergesekkan dengan bodi rumah 
poros berulir. Desain ini kemudian dimodifikasi digerakkan dengan motor listrik. Prototype mesin berukuran $(0,51 \times 0,56 \times 0,7)$ meter dengan berat sekitar $75 \mathrm{~kg}$, termasuk penggerak electromotor $1 / 4$ HP dengan kapasitas produksi $16,2 \mathrm{~kg} / \mathrm{jam}$. Kelebihannya, untuk masyarakat yang belum menggunakan listrik, alat ini dapat digerakkan dengan mesin pembakaran dalam (internal combustion engine).

\subsection{Skinner Dry Soybeans Orbapas type-94}

Tastra (1999) telah menjual pengupas kulit biji kedelai kering tipe Orbapas-94 yang dibuat oleh Balai Penelitian Tanaman Kacang-kacangan dan Umbi-umbian (BALITKABI). Sebelum dikupas, biji kedelai dikukus selama 10 menit untuk menonaktifkan enzim lipoksigenase penyebab citarasa langu, lalu dikeringkan (dioven pada suhu $55^{\circ} \mathrm{C}$ selama 20 jam), setelah itu dikupas kulit biji kedelainya. Orbapas-94 dibuat dari 2 (dua) batu gerinda, masing-masing mempunyai diameter $10 \mathrm{~cm}$ dan panjang $10 \mathrm{~cm}$. Tenaga penggerak yang digunakan adalah tenaga manusia $(75 \mathrm{rpm})$. Kapasitas alat rata-rata $15-20 \mathrm{~kg}$ biji kedelai / jam / orang.

\subsection{Mekanisme Rol Bergesekan Dengan Batu}

Komponen - komponen utama yang digunakan dalam proses ini adalah roll penggiling atau batu beji yang digerakan oleh poros utama dan pully untuk menggerakan rol penggiling (gambar 2.6). Dengan putaran poros utama $1000 \mathrm{rpm}$ daya motor yang digunakan: 0,3675 kw, type JY09A-4 merk: SEM dengan putaran motor listrik $1400 \mathrm{rpm}$ yang digunakan untuk proses pengupasan ulit ari kedelai (Prasetyo, 2006).

\section{DASAR TEORI}

Indikator hasil pengupasan yang baik meliputi :

- Kedelai untuk membuat tempe yang baik adalah kedelai yang terkelupas kulit arinya dengan bantuan alat pengupas kulit ari kedelai.

- Kedelai yang masih terbungkus kulit ari tidak dapat terproses oleh ragi tempe dan akibatnya tempe yang dihasilkan akan busuk. Biji kedelai yang terbelah menjadi 2 (dua) akan menghasilkan tempe yang lebih padat.

- Dengan pencucian berulang-ulang minimal 3 (tiga) kali, maka kulit kedelai akan terkelupas sempurna. Kedelai yang telah bersih itu lantas dijemur kemudian ditaburi ragi, selanjutnya dibungkus dalam plastik dengan kemasan yang berukuran $20 \mathrm{~cm}$ dan $40 \mathrm{~cm}$ dengan tebal $2 \mathrm{~cm}$ sampai $2,5 \mathrm{~cm}$.

Indikator efisiensi proses pengupasan kulit kedelai. Dalam menentukan kemampuan mesin kulit ari kacang kedelai perlu juga diketahui sifat- sifat dari kacang itu sendiri. Biji kacang kedelai berkeping dua terbungkus kulit biji. Pada umumnya bentuk kedelai lonjong, tetapi ada juga yang agak bundar atau bulat pipih dengan besar dan bobot biji kedelai mencapai 5-30 gr untuk bobot 100 butir. Sifat kacang kedelai ini mampu menyerap air cukup banyak dan dapat menyebabkan berat naik menjadi dua kali lipat, dengan sifat biji yang keras dan daya serap air tergantung ketebalan kulit. Kulit inilah yang ingin dikupas secara mekanis dengan semaksimal mungkin tidak membelah kedelai apalagi merusak kedelai sehingga mutu dari kedelai baik dan tetap utuh (TL Damayanthi, 2011).

Efisiensi proses pengupasan kulit kedelai dapat dihitung dengan membagi output (kedelai yang sudah terkelupas) dengan input (volume bahan baku masuk) dikalikan 100\%. Dirumuskan sebagai berikut :

$$
\eta=\frac{\text { output }}{\text { input }} \times 100 \%
$$

Kondisi proses yang mempengaruhi hasil pengupasan terbelah menjadi dua atau lebih. Untuk mekanisme pengupas dan pembelah biji kacang kedelai tersebut ada 
beberapa cara yang dapat dipakai (Saputra, 2004), yaitu :

1. Menggunakan sebuah screw yang berputar. Mekanisme ini memiliki bagian utama berupa sebuah screw dan dinding screw. Screw ini digerakkan oleh sebuah motor yang menggunakan transmisi daya pulley dan belt. Mekanisme ini serupa dengan mekanisme dari mesin pemeras tetapi jarak antara screw dan dinding diperlebar sesuai dengan ukuran biji kacang kedelai. Ketika biji kacang kedelai dimasukkan kedalam mekanisme ini, proses pengupasan dan pembelahan menjadi dua terjadi karena adanya gesekan antara screw dengan biji kacang kedelai dan dengan dinding. Alat ini ditunjukkan pada gambar 2 .

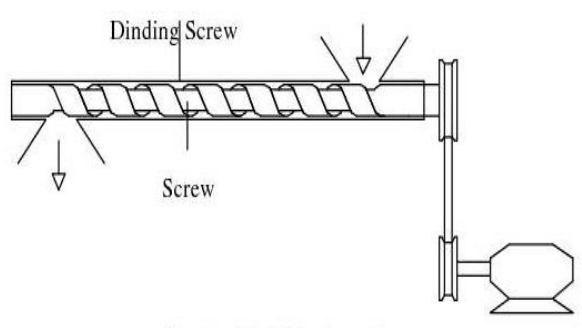

Gambar 2. Mekanisme Screw

(Sumber: Saputra, 2004).

2. Menggunakan dua buah rol karet yang ditata sejajar dan besarnya sama. Dua buah rol ini berputar berlawanan arah tetapi putarannya tidak sama. Kedua rol karet ini digerakkan oleh motor dengan menggunakan transmisi daya pulley dan belt. Pada kedua rol karet ini masingmasing memiliki sebuah roda gigi yang ukuran diameternya berbeda supaya putaran yang dihasilkan antara dua rol karet ini tidak sama. Ketika biji kacang kedelai dimasukkan kedalam mekanisme ini, proses pengupasan terjadi karena adanya gesekan antara rol karet dengan biji kacang kedelai, yang mengakibatkan terkelupas dan terbelahnya biji kacang kedelai. Keuntungan dari mekanisme ini adalah konstruksinya mudah dan hasil pengupasannya cukup banyak, tetapi hasil kupasan yang didapat kurang maksimal. Alat ini ditunjukkan pada gambar 3.
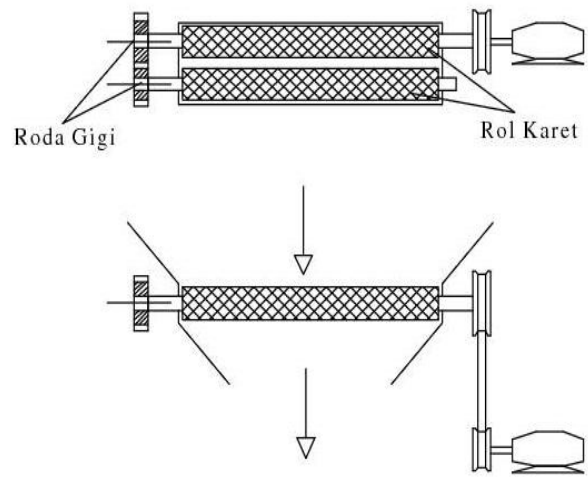

Gambar 3. Mekanisme Rol Karet (Sumber: Saputra, 2004).

Pengaruh kecepatan putaran terhadap kualitas hasil pengupasan. Menurut Sahasto (2010), efisiensi mesin dapat dihitung dengan membagi antara kapasitas aktual dengan kapasitas teoritisnya. Nilai kapasitas aktual diperoleh dari hasil pengamatan massa total kedelai yang keluar dari saluran pengeluaran dengan lama proses pengupasan. Sementara itu kapasitas teoritis di peroleh dari perkalian antara jarak antar celah, kecepatan putar silinder dan keliling dari silinder pengupas dan densitas dari kedelai. Kapasitas teoritis yang terlalu besar ini dipengaruhi oleh kecepatan putaran yang dihasilkan silinder pengupas sangat besar dan diasumsikan kedelai yang masuk kedalam ruang pengupasan menempati semua bagian dari silinder atau volume ruangan diasumsikan terisi penuh. Namun dalam kenyataannya, kedelai ketika dimasukkan kedalam silinder tidak terisi penuh karena apabila ruang pengupasan terisi penuh terjadi penyumbatan kedelai dan mengakibatkan tidak berputarnya silinder pengupas. Semakin cepat kecepatan putar mesin pengupas, maka proses pengupasan kedelai tidak efisien dikarenakan biji kedelai banyak yang hancur menjadi ampas. Pada penelitian tersebut menggunakan mekanisme dua buah silinder 
bergesekan dengan jarak antar celah silinder yang optimum sebesar $4 \mathrm{~mm}$ dan kecepatan putar silinder 313,5 rpm menghasilkan kapasitas kerja sebesar 403,6 kg/jam dan diperoleh efisiensi $18,12 \%$, serta rendemen kedelai terkelupas belah 64,72\%.

Pengaruh clearance space terhadap kualitas hasil pengupasan. Menurut Tamrin (2010), Biji kacang terbelah saat dikupas dengan alat pengupas kulit polong kacang tanah tipe piring ini maksimum dengan menggunakan clearance $5 \mathrm{~mm}$, dengan jumlah yang terbelah sebesar 7,92\% dan biji kacang terbelah terendah dengan menggunakan clearance $15 \mathrm{~mm}$ dengan jumlah yang terbelah $1,27 \%$. Dengan clearance $5 \mathrm{~mm}$, maka daya tekan karet terhadap biji kacang cukup tinggi, maka hal ini berdampak terhadap banyaknya biji kacang terbelah.

\section{RANCANGAN ALAT PENGUPAS KULIT ARI KEDELAI JENIS SCREW}

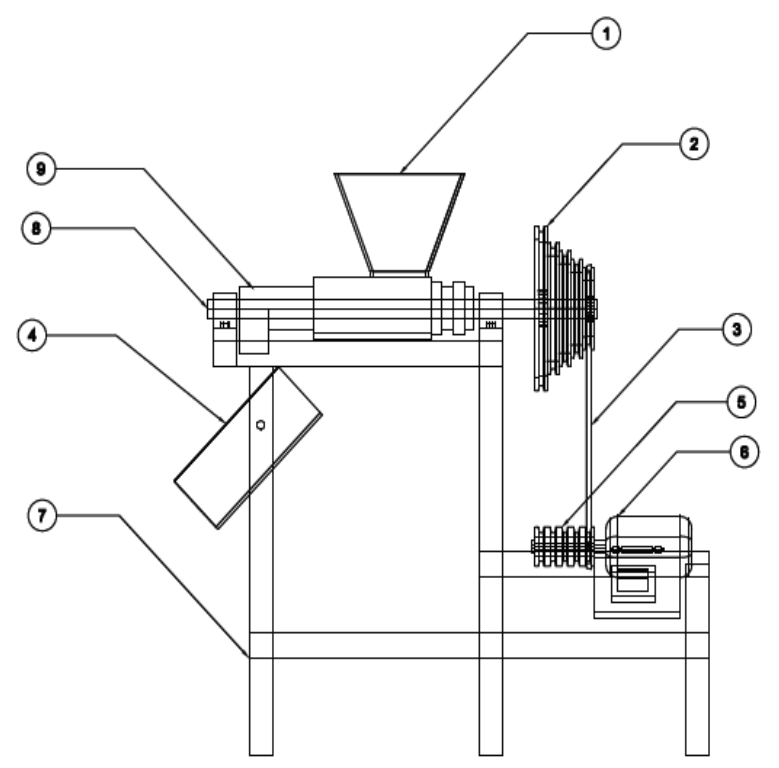

\begin{tabular}{|c|l|}
\hline NO. & \multicolumn{1}{|c|}{ NAME OF ELEMENTS } \\
\hline 1 & Hopper \\
\hline 2 & Pulley \\
\hline 3 & Sabuk (belt) \\
\hline 4 & Corong outlet \\
\hline 5 & Pulley Motor \\
\hline 6 & Electricmotor \\
\hline 7 & Rangka \\
\hline 8 & Silinder Pengupas \\
\hline 9 & Rumah Silinder Pengupas \\
\hline
\end{tabular}

Gambar 4. Alat Pengupas Kulit Ari Kedelai Jenis Screw

a. Rangka dibuat dari besi siku dengan ukuran total alat berukuran panjang 600 $\mathrm{mm}$, tinggi $600 \mathrm{~mm}$ dirangkai dengan pengelasan, saluran masuk dibuat dari besi cor yang kemudian dibentuk plat, sedangkan saluran keluar dibuat dari plat besi dengan ketebalan $2 \mathrm{~mm}$ dan dirangkai dengan mur baut.

b. Pemilihan motor penggerak dengan mempertimbangkan daya yang dibutuhkan dan kemampuan operator dalam menanganinya, maka dipilih motor listrik $1 / 2$ HP dengan putaran maksimal motor 1400 rpm dan kapasitas produksi antara 10 sampai 100 $\mathrm{kg} /$ proses.

c. Jenis sabuk yang digunakan adalah tipe Van Belt A-34. Sedangkan Pulley dibuat dari bahan aluminium cor.

d. Transmisi daya digunakan poros dengan diameter $25 \mathrm{~mm}$ dengan panjang 200 $\mathrm{mm}$.

e. Silinder pengupas awal berbentuk screw dengan diameter $75 \mathrm{~mm}$, panjang 200 $\mathrm{mm}$ dibuat dari aluminium cor, sedangkan silinder pengupas akhir dibuat dengan ukuran diameter $60 \mathrm{~mm}$, panjang $200 \mathrm{~mm}$, dan dengan penambahan pasak pada silinder pengupas akhir. 


\section{TAHAP PENGUJIAN ALAT}

Proses pengujian optimasi dilakukan dengan 2 (dua) variabel, yaitu: (1) variabel kecepatan putar dan (2) variabel clearance space. Selanjutnya pengujian alat dibedakan menjadi dua tahapan, tahapan pertama adalah tahapan persiapan mesin bertujuan untuk memastikan bahwa mesin berfungsi dengan baik sehingga dapat mendukung penelitian ini. Tahapan kedua adalah tahapan pengumpulan data proses penggilingan kedelai dengan kecepatan putar alat yang telah ditentukan. Proses pengujian alat dilakukan sebanyak tiga kali ulangan untuk masing-masing kecepatan putar alat.

\subsection{Parameter Rotation Speed}

$$
\text { (electricmotor) (shaft tool) }
$$

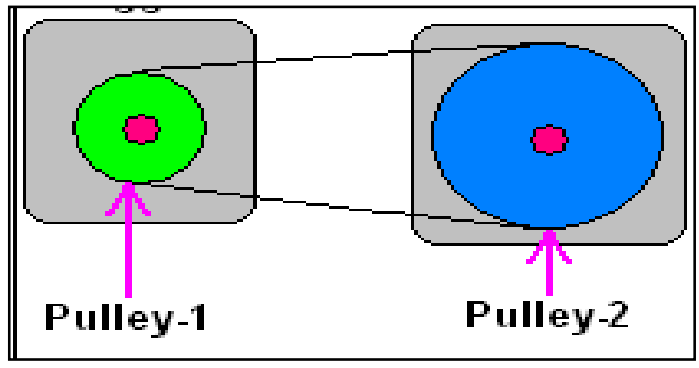

Gambar 5. Parameter Kecepatan Putar

\subsection{Parameter Clearance Space}

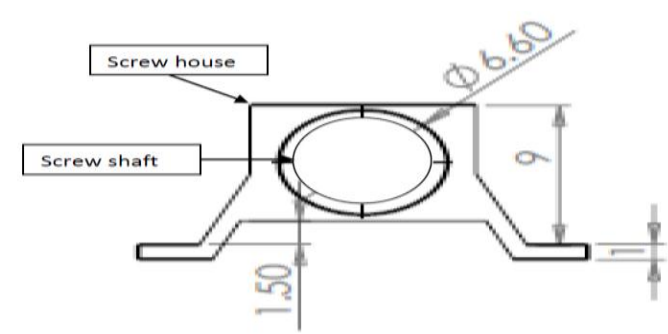

Gambar 6. Rumah Screw.

Biji kedelai yang digunakan sebagai bahan uji kinerja alat adalah biji kedelai yang telah dimasak dan siap untuk di proses. Pengujian dilakukan dengan memvariasikan kecepatan putar pulley yang digerakkan (screw) yaitu pada kecepatan putar 771,6; $643 ; 551 ; 482,1 ; 386 \mathrm{rpm}$, dan clearance space $2 ; 2,25 ; 2,5 \mathrm{~mm}$.

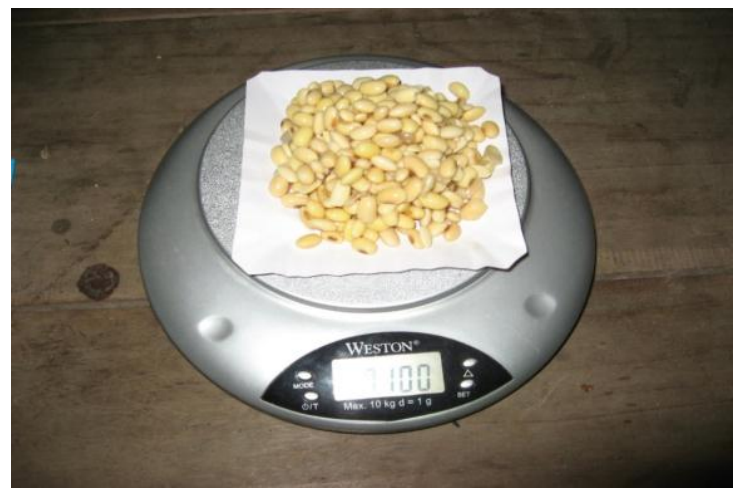

Gambar 7. Biji Kedelai untuk Pengujian Alat

Parameter dari optimasi alat pengupas kulit ari kedelai jenis screw adalah bahwa biji kedelai yang dihasilkan harus memenuhi :

a. Kulit ari terkelupas

b. Biji kedelai terbelah menjadi dua bagian

\section{HASIL PENGUJIAN}

Hasil pengujian dengan menggunakan alat pengupas kulit ari kedelai hasil rancangan terdiri dari berat kedelai terbelah dua dan kulit ari terkelupas. Pengujian dilakukan berulang sebanyak tiga kali untuk masing - masing kecepatan dan diambil rerata dari masing - masing ketiga pengujian tersebut.

\subsection{Data rata - rata pengujian dengan Clearence Space $=2 \mathrm{~mm}$ dan kecepatan putar 386 - 771,6 rpm}

Tabel 2. Hasil Pengujian untuk Clearance Space $2 \mathrm{~mm}$

\begin{tabular}{|c|c|c|c|c|c|c|c|c|c|}
\hline $\begin{array}{l}\text { Kecepatan } \\
\text { Putar } \\
\text { (rpm) }\end{array}$ & $\begin{array}{c}\text { Berat } \\
\text { awal } \\
\text { (gram) }\end{array}$ & $\begin{array}{c}\text { Kedelai } \\
\text { Terbelah } \\
\text { dua } \\
\text { (gram) }\end{array}$ & 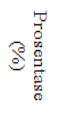 & $\begin{array}{c}\text { Kulit Ari } \\
\text { Kedelai } \\
\text { Terkelupas } \\
\text { (gram) }\end{array}$ & 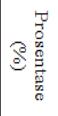 & $\begin{array}{l}\text { Gagal } \\
\text { kupas } \\
\text { (gram) }\end{array}$ & ஓ施 & $\begin{array}{c}\text { Kedelai } \\
\text { terbelah } \\
>2 \\
\text { (gram) }\end{array}$ & 吾 \\
\hline 771,6 & 100 & 39,833 & 40 & 9,167 & 9 & 11,33 & 11 & 39,667 & 40 \\
\hline 643 & 100 & 41,167 & 41 & 10,167 & 10 & 9,33 & 9 & 39,333 & 39 \\
\hline 551 & 100 & 54,000 & 54 & 9,167 & 9 & 12,17 & 12 & 24,667 & 25 \\
\hline 482,1 & 100 & 58,333 & 58 & 10,167 & 10 & 11,33 & 11 & 20,167 & 20 \\
\hline 386 & 100 & 61,333 & 61 & 11,000 & 11 & 9,00 & 9 & 18,667 & 19 \\
\hline
\end{tabular}




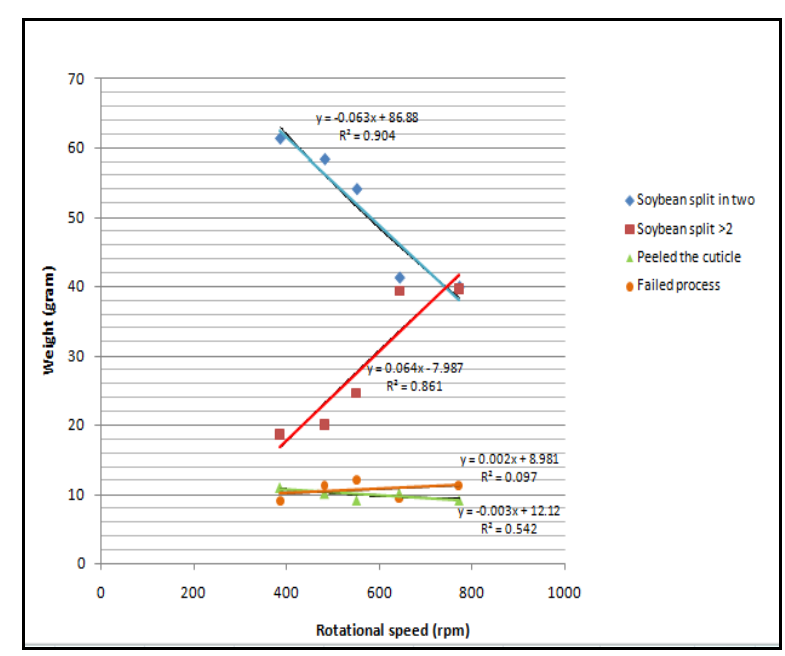

Gambar 8. Grafik Hasil Pengujian untuk Clearance Space $2 \mathrm{~mm}$

Hasil tersebut diatas menyatakan bahwa semakin besar ukuran diameter pulley, maka berat kedelai terbelah dua yang dihasilkan semakin besar pula. Demikian pula dengan hubungan antara kecepatan putar dengan kulit ari terkelupas menghasilkan persamaan $y=-0,003 x+12,12$ dan $R^{2}=0,542$, dan kedelai terbelah $>2$ didapatkan persamaan y $=0,064 x-7,987$ dan $R^{2}=0,861$, sehingga dapat disimpulkan bahwa korelasi yang dihasilkan mendekati angka (+) 1, yang berarti terdapat korelasi atau hubungan yang cukup kuat antara kecepatan putar dengan kapasitas atau berat kedelai.

\subsection{Hasil Pengujian Clearence Space 2,25 mm dan Kecepatan putar 386 - 771,6 rpm}

Tabel 3. Hasil untuk Clearance Space 2,25 mm

\begin{tabular}{|c|c|c|c|c|c|c|c|c|c|}
\hline \begin{tabular}{|l} 
Kecepatan \\
Putar \\
(rpm)
\end{tabular} & $\begin{array}{l}\text { Berat } \\
\text { awal } \\
\text { (gram) }\end{array}$ & $\begin{array}{l}\text { Kedelai } \\
\text { Terbelah } \\
\text { dua } \\
\text { (gram) }\end{array}$ & 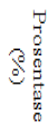 & $\begin{array}{c}\text { Kulit Ari } \\
\text { Kedelai } \\
\text { Terkelupas } \\
\text { (gram) }\end{array}$ & 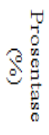 & $\begin{array}{l}\text { Gagal } \\
\text { kupas } \\
\text { (gram) }\end{array}$ & 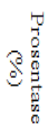 & $\begin{array}{c}\text { Kedelai } \\
\text { terbelah } \\
>2 \\
\text { (gram) }\end{array}$ & 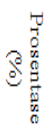 \\
\hline 771,6 & 100 & 43,333 & 43 & 12,500 & 12,5 & 11,500 & 11,5 & 32,667 & 33 \\
\hline 643 & 100 & 42,333 & 42 & 12,667 & 13 & 12,333 & 12 & 32,667 & 33 \\
\hline 551 & 100 & 60,667 & 61 & 12,000 & 12 & 9,83 & 10 & 17,500 & 17,5 \\
\hline 482,1 & 100 & 59,833 & 60 & 13,000 & 13 & 10,17 & 10 & 17,000 & 17 \\
\hline 386 & 100 & 63,667 & 64 & 13,500 & 13,5 & 8,500 & 8,5 & 14,333 & 14 \\
\hline
\end{tabular}

Hasil yang didapat dari ketiga data tersebut diatas menyatakan bahwa semakin besar ukuran diameter pulley yang digunakan, maka kapasitas output yang dihasilkan juga akan semakin besar. Selain itu juga disebabkan karena adanya pengurangan ukuran tinggi pasak pada rumah screw yang memungkinkan biji kedelai akan terproses terbelah dua secara baik, sehingga dapat disimpulkan bahwa korelasi yang dihasilkan mendekati angka (+) 1, yang berarti terdapat korelasi atau hubungan yang kuat antara ukuran diameter pulley dengan kapasitas output kedelai.

Pada pengujian kulit ari terkelupas, hubungan antara kecepatan putar dengan kulit ari terkelupas menghasilkan persamaan $y=-0,002 x+14,05$ dan $R^{2}=0,386$, dengan nilai rata-rata 13 gram, atau didapati koreasi yang $<1$.

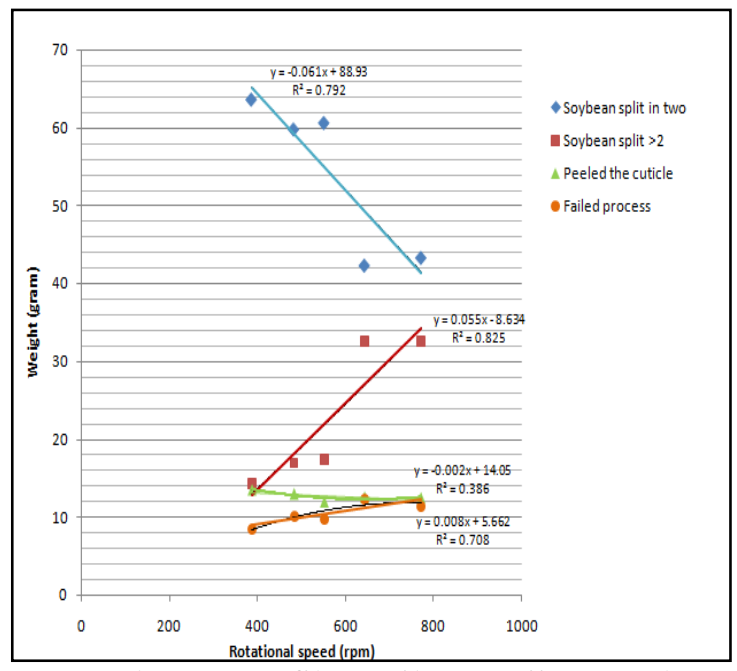

Gambar 9. Grafik Hasil Pengujian untuk Clearance Space $2.25 \mathrm{~mm}$

6.3. Hasil Pengujian Clearence space 2,5 mm dan Kecepatan putar 386 - 771,6 rpm

Tabel 4. Hasil untuk Clearance Space 2,50 mm

\begin{tabular}{|c|c|c|c|c|c|c|c|c|c|}
\hline $\begin{array}{l}\text { Kecepatan } \\
\text { Putar } \\
(\mathrm{pm})\end{array}$ & $\begin{array}{c}\text { Berat } \\
\text { awal } \\
\text { (gram) }\end{array}$ & $\begin{array}{c}\text { Kedelai } \\
\text { Terbelah } \\
\text { dua } \\
\text { (gram) }\end{array}$ & $\overbrace{}^{3}$ & $\begin{array}{c}\text { Kulit Ari } \\
\text { Kedelai } \\
\text { Terkelupas } \\
\text { (gram) }\end{array}$ & 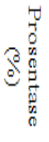 & $\begin{array}{c}\text { Gagal } \\
\text { kupas } \\
\text { (gram) }\end{array}$ & 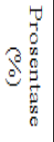 & $\begin{array}{c}\text { Kedelai } \\
\text { terbelah }>2 \\
\text { (gram) }\end{array}$ & 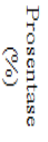 \\
\hline 771,6 & 100 & 73,000 & 73 & 13,000 & 13 & 10,17 & 10 & 1,833 & 2 \\
\hline 643 & 100 & 75,667 & 76 & 13,167 & 13 & 8,67 & 9 & 2,500 & 2,5 \\
\hline 551 & 100 & 78,500 & 79 & 14,000 & 14 & 5,33 & 5 & 1,667 & 2 \\
\hline 482,1 & 100 & 79,667 & 80 & 14,500 & 15 & 5,33 & 5 & 0 & 0 \\
\hline 386 & 100 & 82,167 & 82 & 14,667 & 15 & 3,17 & 3 & 0 & 0 \\
\hline
\end{tabular}




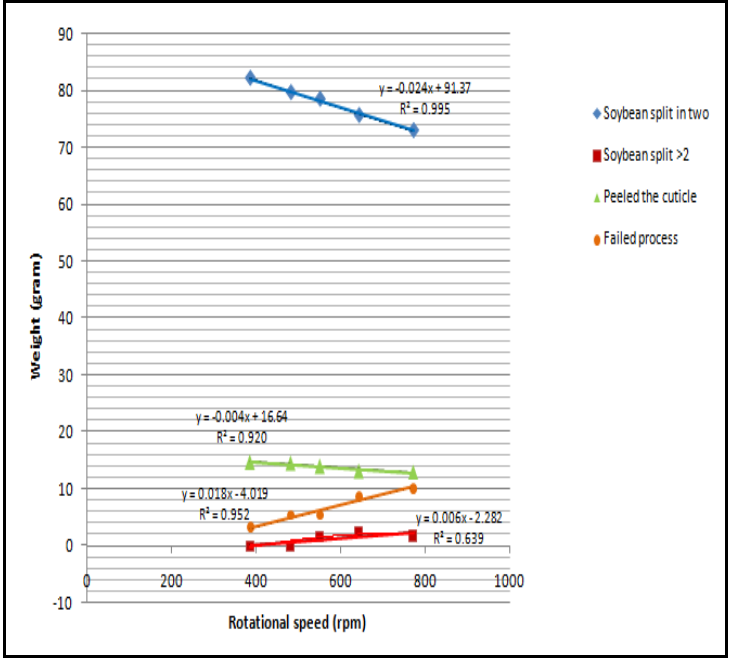

Gambar 10. Grafik Hasil Pengujian untuk Clearance Space 2,50 mm

Hasil yang didapat dari ketiga data tersebut diatas menyatakan bahwa semakin besar ukuran diameter pulley yang digunakan, maka kapasitas output yang dihasilkan juga akan semakin besar. Selain itu juga pada clearance space $2,5 \mathrm{~mm}$ ini sudah didapatkan titik optimal dari ukuran pasak pada rumah screw, sehingga memungkinkan biji kedelai akan terproses terbelah dua secara sempurna, sehingga dapat disimpulkan bahwa korelasi yang dihasilkan mendekati angka (+) 1, yang berarti terdapat korelasi atau hubungan yang kuat antara kecepatan putar (rpm) dengan kapasitas output kedelai.

Pada clearance space $2,5 \mathrm{~mm}$ didapatkan hasil optimal dari pengujian ratarata ukuran diameter bijih kedelai dan berat rata-rata bijih kedelai serta penghitungan gaya sentrifugal yang terjadi pada bijih kedelai sebagai berikut :

a. Diameter kedelai $(\mathrm{d})=5,3 \mathrm{~mm}=0,0053$ $\mathrm{m}$

b. Berat bijih kedelai $(\mathrm{m})=0,32$ gram $=$ $0,00032 \mathrm{~kg}$.

c. Gaya sentrifugal $(\mathrm{Fr})=6,8 \times 10^{-7}$ Newton.

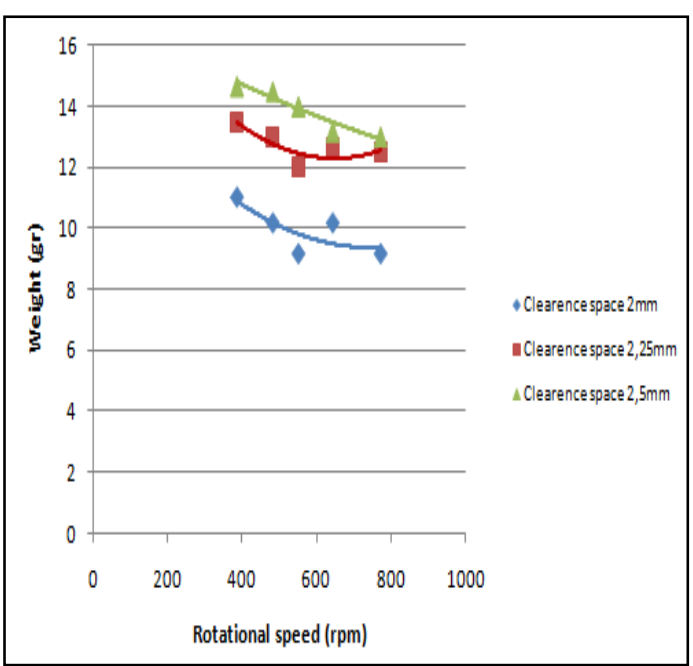

Gambar 11. Grafik untuk Kedelai Terbelah Dua.

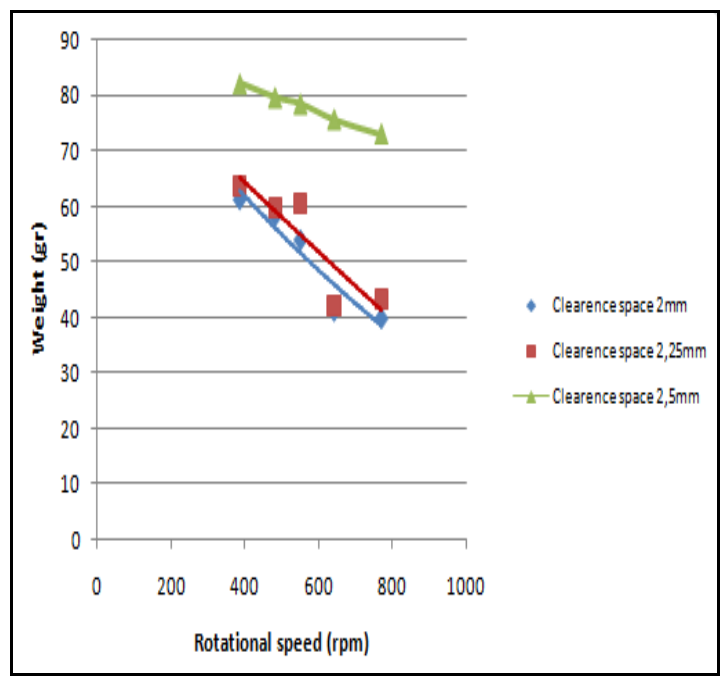

Figure of Soybean split in two

Gambar 12. Grafik Kulit Ari Terkelupas

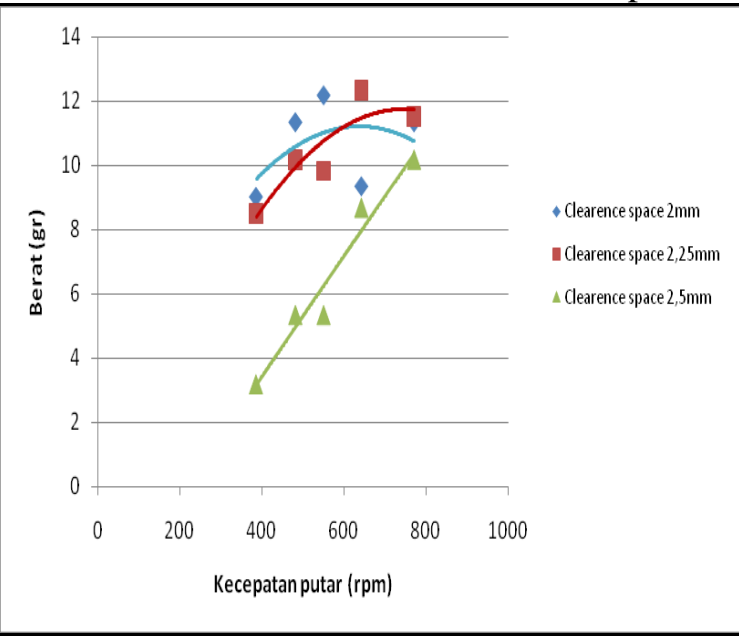

Gambar 13. Gagal Kupas. 


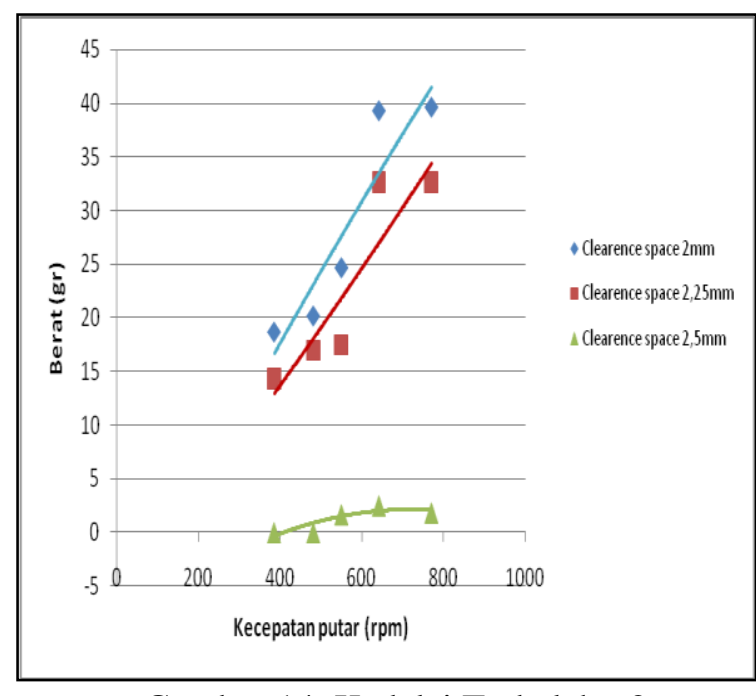

Gambar 14. Kedelai Terbelah >2.

Tabel 5. Hasil Perhitungan tebal bijih kedelai berbanding dengan Clearance Space

\begin{tabular}{cccc}
\hline No & $\begin{array}{c}\text { Tebal } \\
\text { bijih } \\
\text { kedelai } \\
\text { rata-rata } \\
(\mathrm{mm})\end{array}$ & $\begin{array}{c}\text { clearance } \\
\text { space }(\mathrm{mm})\end{array}$ & $\begin{array}{c}\text { Tetapan } \\
\text { (Tebal : } \\
\text { Clearance) }\end{array}$ \\
\hline 1 & & 2 & 2,607 \\
2 & 5,213 & 2,25 & 2,317 \\
3 & & 2,5 & 2,085 \\
\hline
\end{tabular}

Dari hasil perhitungan dan tabel diatas didapatkan bahwa kondisi optimal pengupasan kulit ari kedelai didapat pada clearance space $2,5 \mathrm{~mm}$. Pada kondisi tersebut bijih kedelai akan terproses oleh silinder pengupas (screw) dikarenakan mempunyai berat bijih kedelai > daripada gaya sentrifugal (Fr). Selain itu juga tetapan yang dihasilkan dari perbandingan antara tebal bijih kedelai berbanding dengan clearance space adalah sebesar 2,085 atau $\leq$ 2,5 mm sehingga memungkinkan didapatkan hasil akhir kedelai terbelah dua.

\section{KESIMPULAN DAN SARAN}

\subsection{Kesimpulan}

1. Hasil optimal pada pengujian alat pengupas kulit ari kedelai jenis screw didapatkan bahwa semakin kecil kecepatan putar alat, maka jumlah kedelai terbelah dua yang dihasilkan juga akan semakin besar. Hasil tersebut didapatkan pada kecepatan putar alat 386 rpm dan clearance space $2,5 \mathrm{~mm}$.

2. Penerapan teknologi mesin pengupas kulit ari kedelai jenis screw ini sangat bermanfaat khususnya bagi industri kecil tempe. Hal ini dikarenakan tingkat kebersihan dari produksi makanan tempe akan selalu terjaga.

\subsection{Saran}

Berdasarkan penelitian yang dilakukan, ada beberapa saran guna ditindaklanjuti pada penelitian selanjutnya sebagai berikut :

1. Pada saat proses pengelasan alat pengupas kulit ari kedelai jenis screw sebaiknya jangan langsung dilas mati atau paten tetapi sebaiknya dikeling (rivets) terlebih dahulu. Hal itu bertujuan agar bila terjadi kesalahan dapat dengan mudah dibongkar kembali.

2. Poros silinder pengupas (screw) harus benar-benar berada ditengah-tengah (center) agar perputaran poros stabil. Hal ini dilakukan agar biji kedelai dapat terproses dengan optimal.

3. Sebaiknya biji kedelai yang akan dikupas oleh alat pengupas kulit ari kedelai jenis screw disortasi terlebih dahulu dengan alat sortasi agar lebih seragam.

4. Sebaiknya dilakukan penelitian untuk food grade equipment atau tingkat kelayakan dan kesehatan konsumsi produk pangan.

\section{DAFTAR PUSTAKA}

Damayanthi, T.L, Uji Lama Perebusan dan Lama Pengadukan Terhadap Kualitas Kedelai. Universitas Sumatera Utara, 2011.

Hasim, Mesin Penggiling Kedelai Untuk Pembuatan Tempe. Jurusan Teknik Mesin dan Industri, Fakultas Teknik, Universitas Gadjah Mada, Yogyakarta, 2002. 
Hidayat, Taufik, Bantalan Gelinding. http://www.scribd.com (diakses pada 23/02/2011, 11:30am), 2010.

Hieronymus, B. Sx, SK Mentan No. 501/Kpts/TP.830/8/1984, tentang Teknologi Tepat Guna Pembuatan Tempe dan Tahu Kedelai. Penerbit Kanisius. Yogyakarta, 2010.

Ismanto, Pulley Type V. http://gambarteknik.blogspot.com/2009 /08/pulley-type-v.html

(Diakses 09/09/2013, 09:45am), 2009.

Iswara, Padjar, Kedelai Setelah Satu Dekade. Majalah Tempo (19 Maret 2010).

Jonathan, Sepuluh Tahun Bersama Tempe. Pos Kupang, 2009.

Khurmi, R.S. J.K. Gupta, A Textbook of Machine Design. S.I. Units. Eurasia Publishing House (Pvt) Ltd. New Delhi, 2004.

Murata K., Ikehata H, Studies on the Nutritional Value of Tempeh, Journal of Food Science, 2006.

Passeretti, Sharyn, Preservation of Rhizopus oligosporous spores for Commercial Production of Tempeh from Soybean. Pakistan Journal of Science and Industrial Research, 2002.

Prasetyo, Donny, A, Perancangan Mesin Pengupas Kulit Ari Biji Kacang Kedelai dengan Kapasitas $100 \mathrm{Kg} / \mathrm{jam}$. Jurusan Teknik Mesin, Fakultas Teknik, Universitas Muhammadiyah, Malang, 2006.

Saputra, Eka, D, Perencanaan Mesin Pengupas dan Pemisah Kulit Ari Biji Kedelai Untuk Bahan Dasar Tempe. Jurusan Teknik Mesin, Fakultas Teknologi Industri, Universitas Kristen Petra, Surabaya, 2004.
Sularso, Dasar Perencanaan dan Pemilihan Elemen Mesin. Jakarta : PT. Pradnya Paramita, 2008.

Suryawinata, B, Perencanaan, Pembuatan dan Pengujian Mesin Pengupas Kulit Ari Kacang Kedelai. Jurusan Teknik Mesin Fakultas Teknologi Industri, Universitas Kristen Petra, Surabaya., 2006.

Syarief, R, Wacana Tempe Indonesia. Universitas Katholik Widya Mandala, Surabaya., 1999.

Tamrin, Pengembangan Alat Pengupas Kulit Polong Kacang Tanah Tipe Piring. Jurnal Teknologi Pertanian, Fakultas Pertanian, Universitas Lampung, 2010.

Tastra dan Gatot, Alat Pengupas Biji KedelaiORBAPAS-94. http://pangan.litbang.deptan.go.id/berit a/alat-dan-mesin-pertanian (Diakses 24/02/2011, 10:20am), 1999. 